\title{
ANALISIS JUMLAH PENYEWAAN KAMAR HOTEL MENGGUNAKAN PENTAHO BI BERBASIS DATA WAREHOUSE
}

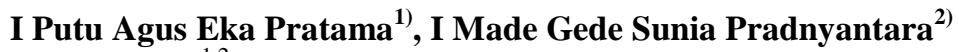 \\ ${ }^{1,2}$ Fakultas Teknik, Universitas Udayana \\ e-mail: eka.pratama@unud.ac.id ${ }^{1)}$, sunia.pradnyantara.sp@gmail.com ${ }^{2}$
}

\begin{abstract}
Hotel Grand Santi as one of the hotels in the city of Denpasar Bali that rents hotel rooms to tourists, until now does not yet have a data-based system, to facilitate them to analyze data and simplify their business reports. This study aims to provide proposed solutions in the form of design and implementation related to hotel room rental data for a month, to make it easier to determine the promotion of equal distribution of all types of hotel rooms. The implementation uses the open-source Pentaho Business Intelligence application to create reports that simplify analysis. Data is created in a multi-dimensional design to facilitate the application of data warehouse design and system design that has been created.
\end{abstract}

Keywords: analysis, business report, data warehouse, pentaho, multi-dimensional data

\section{PENDAhUluan}

Hotel merupakan bisnis jasa akomodasi yang didalamnya terdapa unsur pelayanan, kenyamanan, serta fasilitas penginapan yang dibutuhkan bagi mereka yang menghendaki sarana penginapan untuk kepentingan keluarga maupun liburan. dengan diimbangi majunya dunia penyimpanan digital data, yang dapat memudahkan suatu hotel dalam menyimpan informasi perusahaan pada suatu data warehouse.

Peran data warehouse dalam bidang industri perhotelan sangat dibutuhkan untuk memudahkan suatu pekerjaan yang semula dikerjakan dengan cara yang konvensional, kini dapat dikerjakan dengan efisien atau menghemat waktu, penyimpanan suatu data informasi yang sangat aman dan rahasia yang memungkinkan orang lain sulit untuk mendapatkan informasi-informasi yang disimpan dalam data warehouse.

Oleh karena itu penulis melakukan sebuah penelitian dengan mengimplementasikan data warehouse pada Hotel Grand Santhi yang terletak di Jl. Patih Jelantik No.1, Dauh Puri Klod, Kecamatan Denpasar Barat, Kota Denpasar, Bali. Tujuan nya diantara lain untuk memperolah informasi, memberikan prediksi, dan saran, serta kesimpulan berupa penentuan promosi pada ruang penginapan yang ada pada Grand Santhi Hotel.

Solusi yang penulis usulkan untuk permasalahan yang dimiliki Hotel Grand Santhi adalah menerapkan sistem Data Warehouse pada Hotel Grand Santhi.
Beberapa fungsi yang dimiliki dari sistem Data Warehouse adalah fungsi sebagai analisa dan laporan penyewaan penginapan jenis kamar hotel yang paling sering disewa hingga jenis kamar hotel yang paling sedikit disewa dalam kurun waktu satu bulan, sehingga memudahkan pemilik hotel dalam pengambilan keputusan dalam memberikan suatu promosi untuk penyewaan penginapan jenis kamar hotel yang paling sedikit disewa, agar penyewaan seluruh jenis kamar hotel yang dimiliki oleh Hotel Grand Santhi merata.

Solusi yang tepat adalah dengan menggunakan tools open source Pentaho Business Inteligence yang memiliki fitur yang dibutuhkan, selain itu pemilihan tools ini karena memiliki tampilan yang user friendly dan dapat dipahami dengan mudah oleh semua kalangan masyarakat.

\section{METODE PENELITIAN}

Penelitian dilakukan melalui beberapa tahapan seperti flowchart penelitian dan rancangan desain sistem 


\section{Vol.3 No.1, Agustus 2020}

1) Flowchart Penelitian

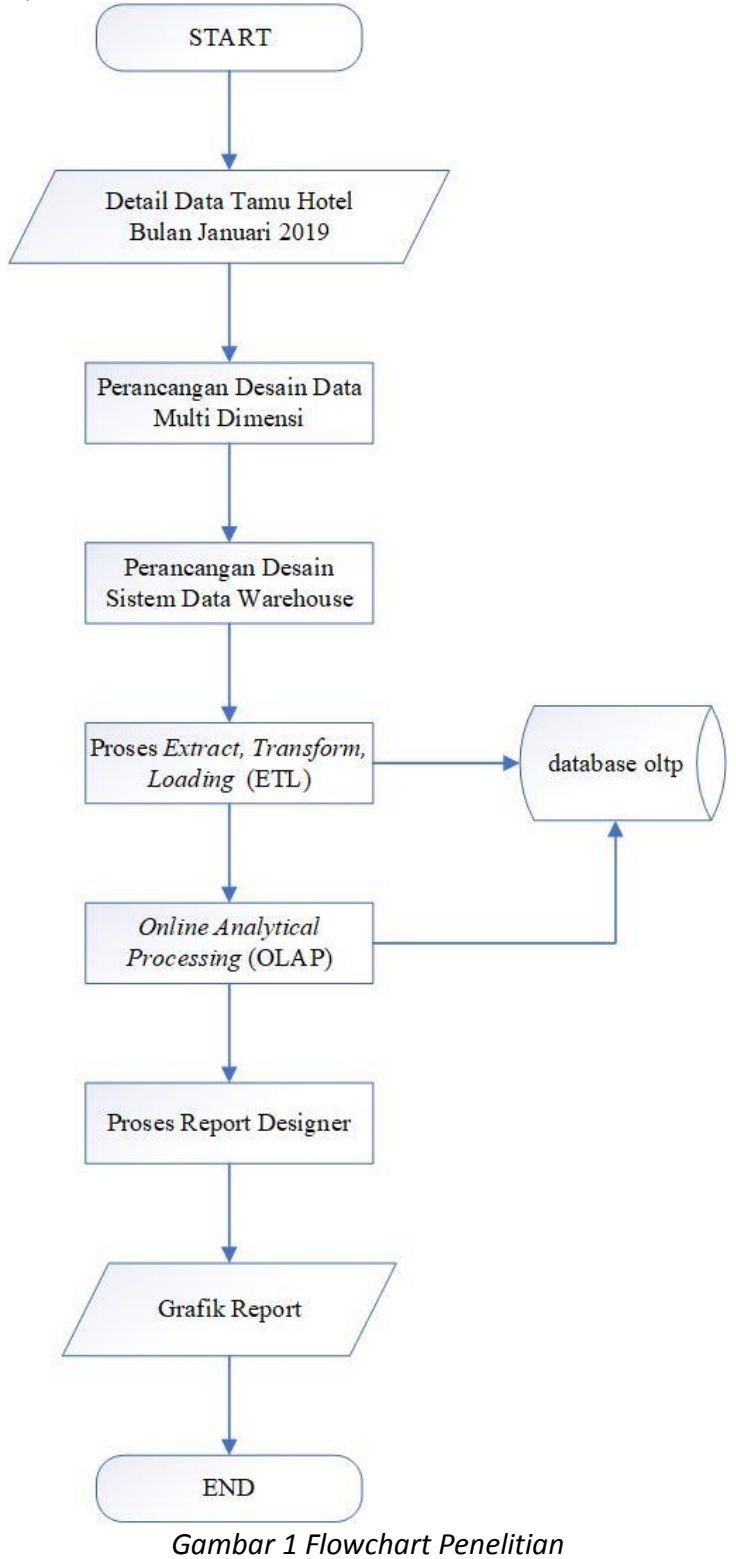

Gambar 1 merupakan diagram alir penelitian yang memberikan informasi tentang tahapan-tahapan dari analisis paper ini, dimulai dari perolehan detail data tamu hotel bulan januari 2019 dalam bentuk format .xls, lalu perancangan desain data multi dimensi yang berguna dalam pengolahan data warehouse, dilanjutkan dengan perancangan desain sistem data warehouse yang akan memberikan gambaran tentang proses pembuatan data warehouse, setelah itu dilakukan proses pembentukan data warehouse yaitu dengan cara, Extract, Transform, Loading (ETL) dan Online Analytical Processing (OLAP). Proses Report Designer dilakukan apabila data warehouse sudah berhasil dibentuk, dan hasil dari proses tersebut berupa grafik report.

\section{2) Perancangan Desain Sistem}

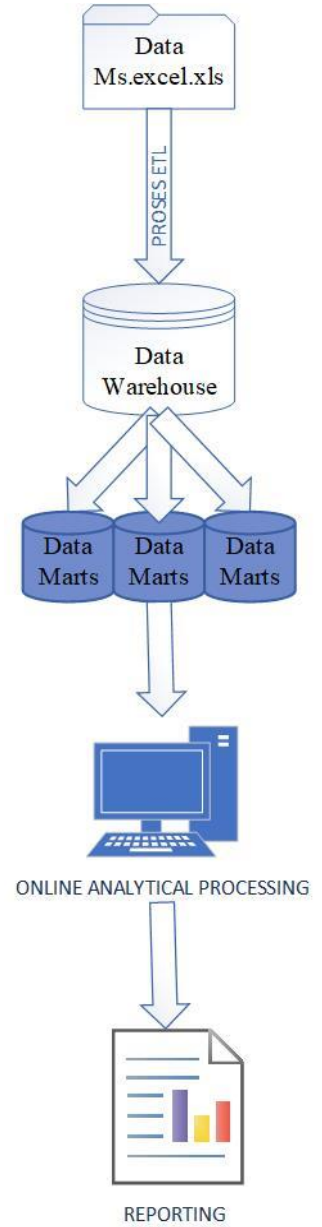

Gambar 2 Perancangan Desain Sistem

Gambar diatas menunjukan desain sistem data warehouse yang dimulai dari sumber data berbentuk format .xls, isinya berupa laporan tamu menginap kemudian melewati proses ETL untuk dsimpan ke dalam data warehouse sehingga menghasilkan laporan analisis jenis kamar hotel yang paling banyak ataupun paling sedikit yang disewa oleh tamu.

\section{HASIL DAN PEMBAHASAN}

1) Detail Data Tamu Hotel Bulan Januari 2019

\begin{tabular}{|c|c|c|c|c|c|c|c|c|c|c|c|c|}
\hline$\triangle A$ & $B$ & c & 0 & E & $\mathrm{f}$ & G & H & I & J & k & L & M \\
\hline 1 NO & ROOM & TYPE & GULST_ MAME & GENDER & ARRVALL & DEPART & BITHDAY & NATIONALTY & VIP & NIGGT & PAK & AGENT \\
\hline 21 & 101 & DUXT & DARLAN STUWART & MALE 3 & 31/12/2/2018 & $02 / 01 / 2019$ & 17/07/1966 & INDONESIA & N & 2 & 2 & TRAVELOKA \\
\hline 32 & 102 & DUXT & RAMLI & MALE 3 & 31/12/2018 & $02 / 01 / 2019$ & $29 / 121 / 993$ & INDONESSA & N & 2 & & WALIIN GUEST \\
\hline 43 & 103 & DUXT & NETUT BUDLASIH & FEMALE 0 & $01 / 01 / 2019$ & $02 / 01 / 2019$ & $22 / 04 / 9975$ & INDONESIA & N & 1 & 2 & TRAVELOKA \\
\hline 54 & 105 & DUXT & FrANSISCUSXAVERUIS & MALE 2 & 27/12/2018 & $02 / 01 / 2019$ & $29 / 05 / 1973$ & INDONESIA & N & 6 & 2 & TIKET.COM \\
\hline 65 & 107 & DUXT & RZZQY P PATAMAM d & MaLE 0 & 01/01/2019 & $02 / 01 / 2019$ & 21/11/1997 & INDONESIA & N & 1 & & WALIIN GUEST \\
\hline
\end{tabular}




\section{Vol.3 No.1, Agustus 2020}

Gambar 3 menunjukkan data room, type yang merupakan type room, guest_name, gender, arrival yang merupakan check-in, depart yang merupakan check-out, birthday, nationality, vip yang merupakan jenis booking, nights yang merupakan jumlah malam tamu menginap, pax yang merupakan jumlah orang menginap, dan terakhir yaitu agent merupakan pihak ketiga. Jumlah detail data tamu hotel pada bulan januari berjumlah 423 data.

\section{2) Perancangan Desain Data Multi Dimensi}

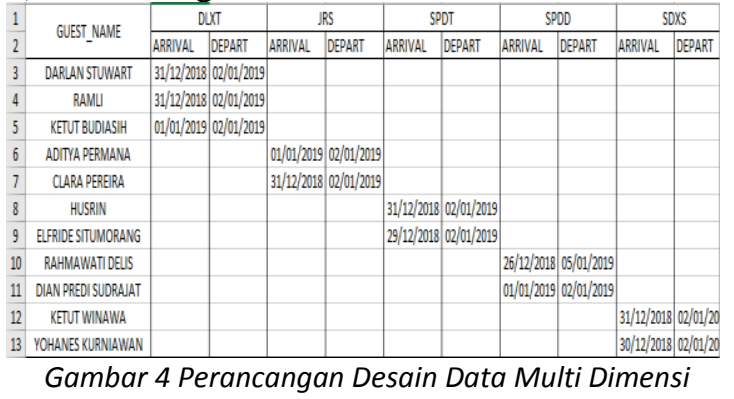

Gambar 4 menunjukkan desain perancangan data multi dimensi berbentuk tabel dimana terdapat tiga dimensi yang telah dirancang pada desain data warehouse. Pertama terdapat dimensi guest, dimensi booking, dan dimensi date. Untuk melihat data kamar yang paling banyak ataupun paling sedikit yang disewa oleh tamu, data multi dimensi tersebut lebih mudah untuk dilakukan proses analisa dibandingan dengan menggunakan data dua dimensi.

3) Perancangan Desain Data Warehouse

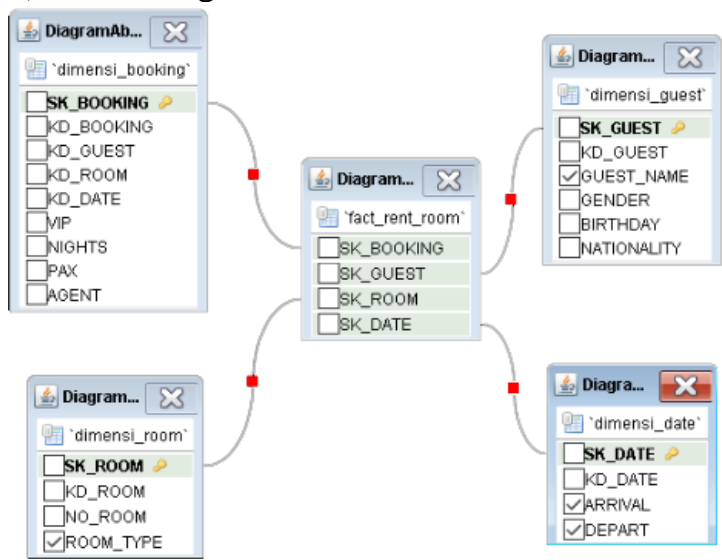

Gambar 5 Perancangan Desain Data Warehouse

Gambar 5 menunjukan desain data warehouse dalam bentuk OLAP untuk mengetahui Fact_rent_room dibutuhkan empat dimensi yakni : dimensi guest, dimensi booking, dan dimensi date. Dimensi_guest menunjukkan SK_GUEST, KD_GUEST, GUEST_NAME, GENDER, BIRTHDAY, NATIONALITY. Kemudian dimensi_booking menunjukkan SK_BOOKING, KD_BOOKING, KD_GUEST, KD_ROOM, KD_DATE, VIP merupakan jenis booking, NIGHTS, PAX merupakan jumlah orang yang menginap, AGENT yang merupakan pihak ketiga saat melakukan booking penginapan. Dimensi_date yang berisi SK_DATE, KD_DATE, ARRIVAL yang merupakan waktu saat tamu check-in, DEPART yang merupakan waktu saat tamu check-out, dimensi terakhir adalah dimensi_room menampilkan SK_ROOM, KD_ROOM, NO_ROOM, ROOM_TYPE.

\section{4) Pembahasan}

Berdasarkan hasil dari sumber data diatas maka akan dimasukkan ke dalam Pentaho BI sehingga akan terlihat seperti gambar dibawah ini.

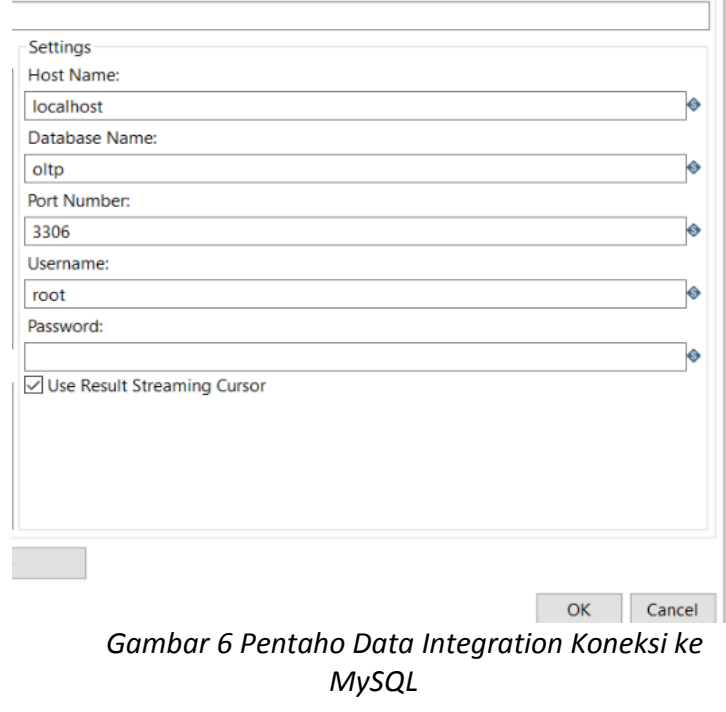

Gambar 6 menampilkan koneksi ke database MySQL dengan nama database oltp pada aplikasi data-integeration Pentaho BI untuk melakukan proses integrasi data warehouse. Dilakukan test koneksi dengan hasil notifikasi berhasil terhubung dengan database. 
Vol.3 No.1, Agustus 2020

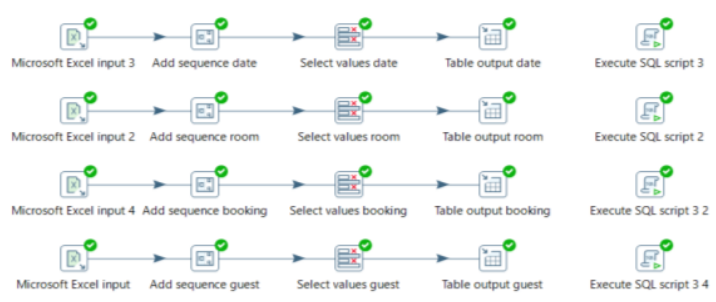

Gambar 7 Proses Extract Transform Load (ETL)

Gambar 7 merupakan tampilan pembuatan Extract, Transform, Loading (ETL) dengan sumber data Microsoft excel lalu akan dibentuk menjadi 4 dimensi yang diantaranya, dimensi date, dimensi room, dimensi booking, dan dimensi guest. Seluruh dimensi akan dimasukan pada database oltp.

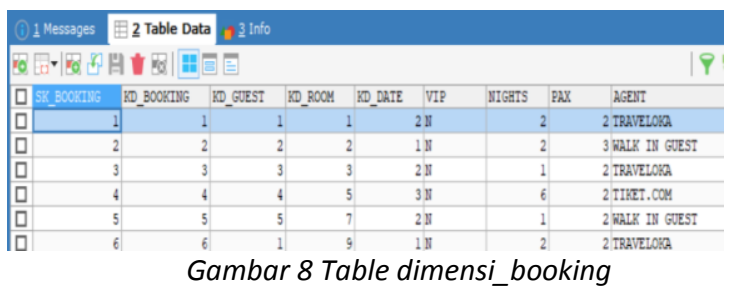

Gambar 8 menampilkan isi table dimensi_booking pada MySQL dari database oltp, yang sebelumnya telah dilakukan proses ETL pada Gambar 6 dengan sumber data dari Microsoft excel Detail Data Tamu Hotel.

\begin{tabular}{|c|c|c|c|c|}
\hline \multicolumn{2}{|c|}{ (C) 1 Messages } & \multicolumn{3}{|c|}{ 国 2 Table Data $n \underline{3}$ Info } \\
\hline To & {$[\mathrm{E} \cdot 1 \mathrm{ES}$} & 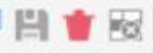 & 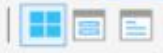 & \\
\hline$\square$ & SK_ DAIE & KD_DATE & ARRIVAL & DEPART \\
\hline$\square$ & 1 & 1 & $2018-12-31$ & $2019-01-02$ \\
\hline$\square$ & 2 & 2 & 2019-01-01 & 2019-01-02 \\
\hline$\square$ & 3 & 3 & $2018-12-27$ & 2019-01-02 \\
\hline$\square$ & 4 & 4 & $2018-12-26$ & 2019-01-02 \\
\hline$\square$ & 5 & 5 & $2018-12-31$ & 2019-01-03 \\
\hline$\square$ & 6 & 6 & $2018-12-29$ & 2019-01-02 \\
\hline$\square$ & 7 & 7 & $2018-12-30$ & 2019-01-02 \\
\hline$\square$ & 8 & 8 & $2018-12-26$ & 2019-01-05 \\
\hline$\square$ & 9 & 9 & $2018-12-31$ & 2019-01-04 \\
\hline$\square$ & 10 & 10 & 2019-01-03 & 2019-01-04 \\
\hline$\square$ & 11 & 11 & 2019-01-01 & 2019-01-04 \\
\hline$\square$ & 12 & 12 & $2019-01-03$ & 2019-01-05 \\
\hline$\square$ & 13 & 13 & 2019-01-02 & 2019-01-04 \\
\hline$\square$ & 14 & 14 & 2019-01-04 & 2019-01-05 \\
\hline 口 & 15 & 15 & 2019-01-05 & 2019-01-06 \\
\hline
\end{tabular}

Gambar 9 menampilkan isi table dimensi_date pada MySQL dari database oltp, yang sebelumnya diproses ETL pada Gambar 6 dengan menggunakan sumber data Microsoft excel Detail Data Tamu Hotel.

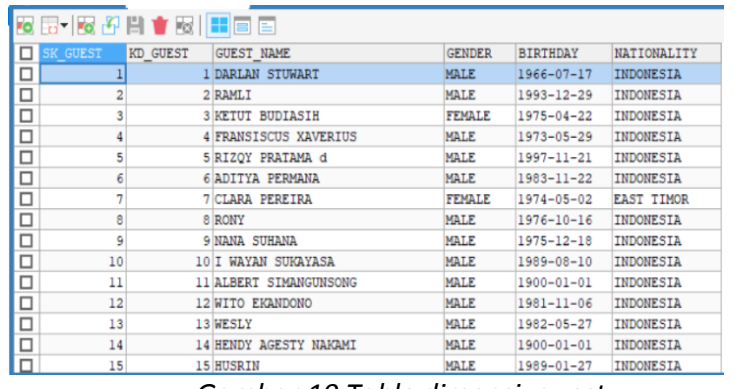

Gambar 10 Table dimensi_guest

Gambar 10 manampilkan isi table dari dimensi_guest pada database oltp, yang telah diproses dengan ETL pada gambar 6 dengan menggunakan sumber data Microsoft excel Detail Data Tamu Hotel.

\begin{tabular}{|c|c|c|c|c|}
\hline \multicolumn{2}{|c|}{ (i) 1 Messages } & \multicolumn{3}{|c|}{ 国 2 Table Data $n \underline{3}$ Info } \\
\hline (e) & $E \cdot \mid \overrightarrow{E S}$ & 빌 & 부료 & \\
\hline$\square$ & SK_ROOM & KD_ROOM & NO_ROOM & ROOM_TYPE \\
\hline$\square$ & 1 & 1 & 101 & DLXT \\
\hline$\square$ & 2 & 2 & 102 & DLXT \\
\hline$\square$ & 3 & 3 & 103 & DLXI \\
\hline$\square$ & 4 & 4 & 104 & DLXT \\
\hline$\square$ & 5 & 5 & 105 & DLXI \\
\hline$\square$ & 6 & 6 & 106 & DLXT \\
\hline$\square$ & 7 & 7 & 107 & DLXT \\
\hline$\square$ & 8 & 8 & 108 & DLXT \\
\hline$\square$ & 9 & 9 & 109 & DLXI \\
\hline$\square$ & 10 & 10 & 110 & JRS \\
\hline$\square$ & 11 & 11 & 111 & JRS \\
\hline$\square$ & 12 & 12 & 112 & JRS \\
\hline$\square$ & 13 & 13 & 114 & JRS \\
\hline$\square$ & 14 & 14 & 115 & JRS \\
\hline$\square$ & 15 & 15 & 116 & JRS \\
\hline
\end{tabular}

Gambar 11 menampilkan isi table dari dimensi_room pada database oltp, yang telah diproses ETL sebelumnya pada gambar 6 dengan sumberdata dari Microsoft excel Detail Data Tamu Hotel.

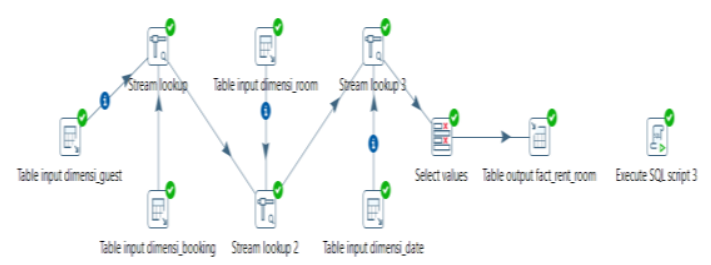

Gambar 12 Proses Online Analytical Processing (OLAP)

Gambar 12 merupakan tampilan proses pembuatan Online Analytical Processing (OLAP) dengan 4 dimensi yang telah dibentuk pada proses ETL sebelumnya, 4 dimensi tersebut diantaranya, dimensi_guest, dimensi_room, dimensi_date, dan 


\section{Vol.3 No.1, Agustus 2020}

dimensi_booking. Hasil dari proses Online Analytical Processing (OLAP) akan disimpan pada database oltp dengan nama table fact_rent_room

\begin{tabular}{|c|c|c|c|c|}
\hline$\square$ & SK_BOOKING & SK_GUEST & SK_ROOM & SK_DATE \\
\hline$\square$ & 1 & 1 & 1 & 2 \\
\hline$\square$ & 2 & 2 & 2 & 1 \\
\hline$\square$ & 3 & 3 & 3 & 2 \\
\hline$\square$ & 4 & 4 & 5 & 3 \\
\hline$\square$ & 5 & 5 & 7 & 2 \\
\hline$\square$ & 6 & 1 & 9 & 1 \\
\hline 口 & 7 & 4 & 12 & 4 \\
\hline$\square$ & 8 & 6 & 13 & 1 \\
\hline$\square$ & 9 & 7 & 14 & 1 \\
\hline 口 & 10 & 8 & 17 & 5 \\
\hline 口 & 11 & 8 & 19 & 5 \\
\hline$\square$ & 12 & 9 & 21 & 5 \\
\hline$\square$ & 13 & 9 & 22 & 5 \\
\hline 口 & 14 & 10 & 24 & 1 \\
\hline 口 & 15 & 11 & 25 & 1 \\
\hline
\end{tabular}

Gambar 13 merupakan hasil dari proses Online Analtytical Processing (OLAP). Dengan hasil OLAP berupa table fact_rent_room, Isi dari table fact_rent_room berupa SK_BOOKING yang berasal dari dimensi_booking, SK_GUEST berasal dari data dimensi_guest, SK_ROOM berasal dari dimensi_room, dan SK_DATE yang berasal dari dimensi_date.

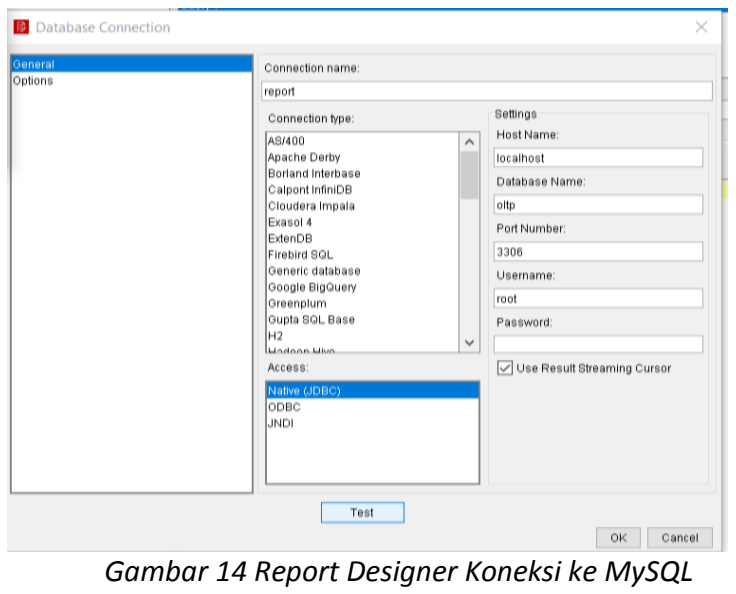

Gambar 14 menampilkan koneksi ke database MySQL dengan nama koneksi report dan nama database oltp pada aplikasi reportdesigner Pentaho BI. Tujuan penggunaan aplikasi ini untuk melakukan proses reporting atau laporan hasil. Test koneksi dilakukan dengan hasil notifikasi berhasil terhubung dengan database.

\begin{tabular}{|c|c|c|c|}
\hline \multicolumn{4}{|l|}{ 目 Preview } \\
\hline QUEST_NAME & ROOM_TYPE & ARRIVAL & DEPART \\
\hline DARLAN STUNART & DLXT & $\operatorname{Jan} 1,2019$ & $\operatorname{Jan} 2,2019$ \\
\hline RAMLI & DLXT & Dec 31, 2018 & $\operatorname{Jan} 2,2019$ \\
\hline KETUT BUDIASIH & DLT & Jan 1, 2019 & $\operatorname{Jan} 2,2019$ \\
\hline FRANSISCUSXAVERIUS & DLXT & Dec 27,2018 & $\operatorname{Jan} 2,2019$ \\
\hline RIZQY PRATAMA d & DLXT & Jan 1, 2019 & $\operatorname{Jan} 2,2019$ \\
\hline
\end{tabular}

Gambar 15 menampilkan preview data GUEST_NAME yang berasal dari dimensi_guest, ROOM_TYPE berasal dari dimensi_room, ARRIVAL dan DEPART yang berasal dari dimensi_date. Seluruh data tersebut akan ditampilkan dalam pembuatan report jenis kamar apa saja yang paling banyak hingga paling sedikit disewa, sehingga pemiliki hotel dapat menentukan dan memberikan suatu promosi terhadap kamar yang kurang sering disewa dalam menciptakan pemerataan seluruh jenis kamar yang ada pada Hotel Grand Santhi.

\begin{tabular}{|c|c|}
\hline 圆 Preview & $x$ \\
\hline ROON_TPE & RENT_ROOM_TOTHL \\
\hline DLVT & 165 \\
\hline JRR & 60 \\
\hline 80X8 & \\
\hline SPDD & 132 \\
\hline SPOT & 63 \\
\hline
\end{tabular}

Gambar 16 menampilkan preview data ROOM_TYPE yang merupakan jenis kamar berasal dari dimensi_room, isi field ROOM_TYPE berupa DLXT, JRS, SDXS, SPDD, SPDT. RENT_ROOM_TOTAL atau total sewa kamar isinya berupa jenis kamar DLXT yang disewa sejumlah 165 kali, jenis kamar JRS di sewa sejumlah 60 kali, jenis kamar SDXS disewa sejumlah 3 kali, jenis kamar SPDD disewa sejumlah 132, dan jenis kamar terakhir yaitu SPDT di sewa sejumlah 63. Total seluruh jenis kamar yang disewa selama satu bulan adalah 423 kali. 
Vol.3 No.1, Agustus 2020

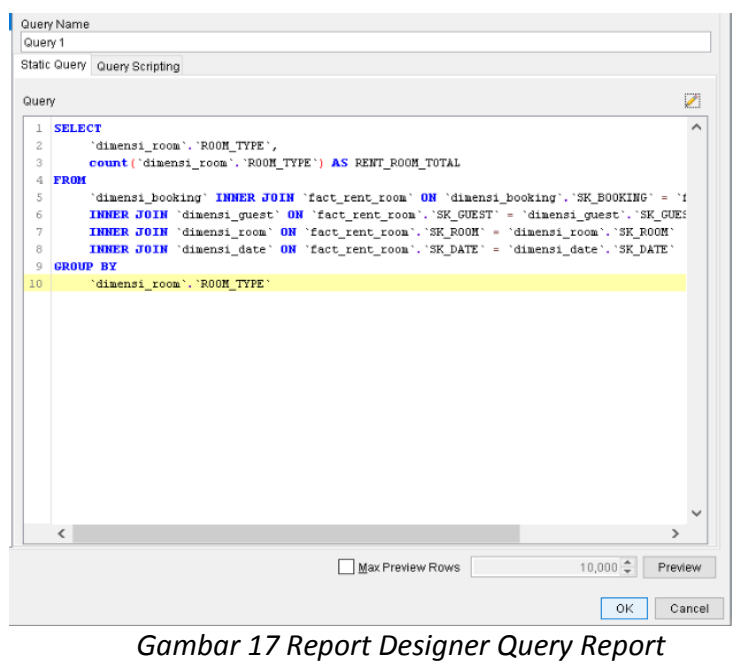

Gambar 17 menampilkan query database MySQL untuk membentuk suatu report dari dimensi_booking, dimensi_guest, dimensi_room, dan dimensi_date. Data yang ditampilkan berupa ROOM_TYPE dan hasil perhitungan ROOM_TYPE selama bulan januari dihitung dengan menggunakan query count.

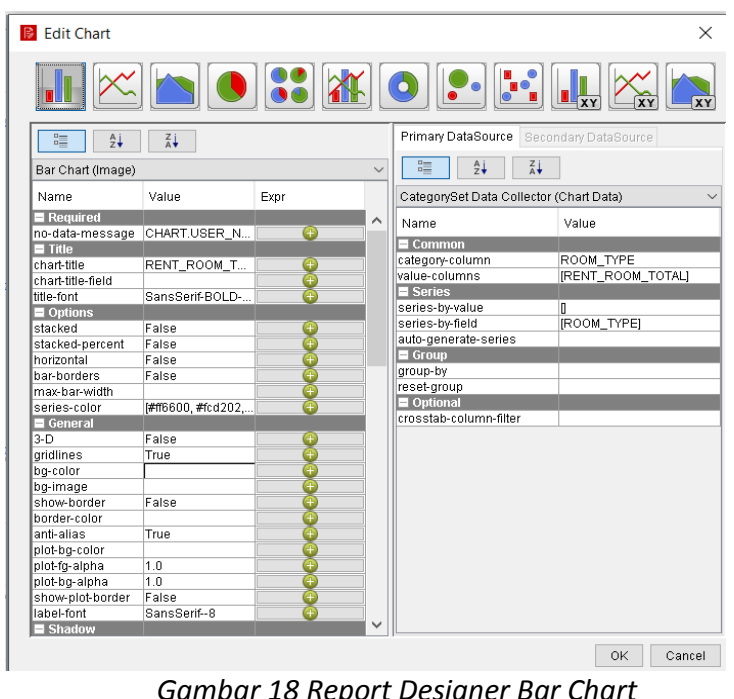

Gambar 18 menampilkan bar chart pada report-designer pentaho yang berfungsi untuk memberikan visualisasi report dalam bentuk bar chart. ROOM_TYPE diatur sebagai Category-column, dan RENT_ROOM_TOTAL diatur sebagai valuescolumns dengan series-by-field adalah ROOM_TYPE. Lalu bar chart akan mulai dibentuk dengan chart-title RENT_ROOM_TOTAL

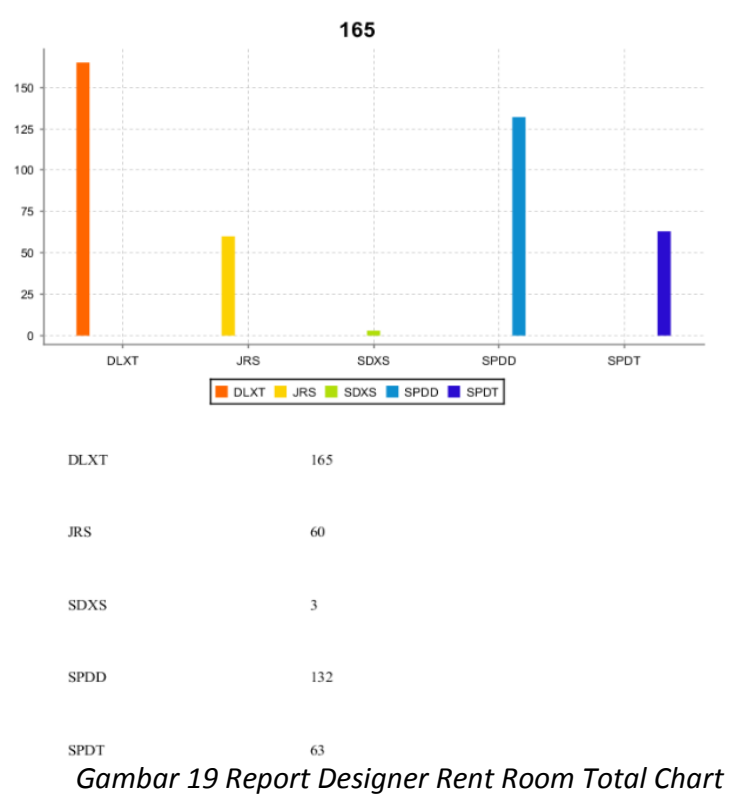

Gambar 19 merupakan tampilan dari Rent Room Total Chart bar dengan 5 jenis ROOM_TYPE yang diantara. Jenis kamar DLXT dengan total sewa sejumlah 165 kali, disusul dengan SPDD dengan total sewa sejumlah 132 kali, SPDT dengan total sewa sejumlah 63 kali, JRS disewa sejumlah 60 kali, dan SDXS disewa sejumlah 3 kali, jadi total seluruh jenis kamar yang disewa selama bulan januari sebanyak 423 kali. Berdasarkan gambar 18 dapat disimpulkan bahwa penyewaan jenis kamar terbanyak oleh tamu adalah jenis kamar DLXT dan jenis kamar yang paling sedikit atau jarang disewa oleh tamu adalah jenis kamar SDXS. Setelah mengetahui hasil laporan dari report-designer pentaho BI, Pihak hotel dapat mengambil keputusan dalam memberikan suatu promosi kepada jenis kamar yang paling sedikit disewa dalam kurun waktu satu bulan agar menciptakan pemerataan seluruh jenis kamar pada Hotel Grand Santhi.

\section{KESIMPULAN}

Dari Penjelasan diatas maka dapat disimpulkan bahwa data warehouse sangat bermanfaat di implementasikan dalam segala bidang yang dimiliki salah satu nya dalam bidang bisnis parawisata. Adapun kesimpulan lainnya yang didapat dari paper data warehouse ini yaitu.

1) Data warehouse tidak hanya menjadi Gudang data, tetapi dapat digunakan juga sebagai pembuatan suatu laporan analisis data dengan mudah, cepat, dan efisien 
Vol.3 No.1, Agustus 2020

2) Diperlukan nya data multi dimensi dalam pembuatan suatu data warehouse sehingga perlu pengubahan dari data konvensional

3) Pentaho Business Intelligence dapat digunakan sebagai salah satu solusi yang bermanfaat dalam pembuatan report total penyewaan seluruh jenis kamar pada Hotel Grand Santhi

\section{REFERENSI}

Ardista, N., Purbandini, P., \& Taufik, T. (2017). Rancang Bangun Data Warehouse Untuk Pembuatan Laporan dan Analisis pada Data Kunjungan Pasien Rawat Jalan Rumah Sakit Universitas Airlangga Berbasis Online Analytical Processing (OLAP). Journal of Information Systems Engineering and Business Intelligence, 3(1), 40. https://doi.org/10.20473/jisebi.3.1.40-51

Ozmar, A. (2016). THE DATA WAREHOUSE IMPLEMENTATION BY COMBINING KIMBALL AND INMON METHOD (Study Case In Data Warehouse Of Video Surveillance For Automated Teller Machine In Banking Industry). Jurnal Teknologi Informasi, 12(2), 54-63.

Pratama, I. P. A. E. (2018). Handbook Data Warehouse. Bandung.

Suni, E. K. (2018). Analisis Dan Perancangan Data Warehouse Untuk Mendukung Keputusan Redaksi Televisi Menggunakan Metode Nine-Step Kimball. Jurnal Teknik Informatika, 11(2), 197-206. https://doi.org/10.15408/jti.v11i2.8560

Umam, Q., Wicaksono, S. A., \& Purnomo, W. (2019). Analisis Dan Perancangan Data Warehouse Menggunakan Pendekatan ( Studi Pada Dinas Komunikasi dan Informatika Kabupaten Sidoarjo ). 3(2), 1824-1833.

Nejres, S. M. (2015). Analysis of Data Warehousing and Data Mining in Education Domain. International Journal of Advances in Computer Science and Technology, 4(4). 